\title{
Hybridization and cellular uptake properties of lipophilic oligonucleotide-dendrimer conjugates
}

\author{
Konstantinos Skobridis*a , Dieter Hüsken ${ }^{\text {b }}$, Paul Nicklin, and Robert Häner*d \\ ${ }^{a}$ Department of Chemistry, University of Ioannina, GR-451 10 Ioannina, Greece \\ ${ }^{b}$ Novartis Institutes of Biomedical Research, CH-4002 Basel, Switzerland \\ ${ }^{c}$ Novartis Institutes of Biomedical Research, Horsham, UK \\ ${ }^{d}$ Department of Chemistry and Biochemistry, Freiestrasse 3, CH-3012 Bern, Switzerland \\ E-mail: kskobrid@cc.uoi.gr
}

\section{Dedicated to Prof. Eusebio Juaristi on the occasion of his $55^{\text {th }}$ birthday \\ (received 28 Jun 05; accepted 25 Sept 05; published on the web 06 Oct 05)}

\begin{abstract}
Dendrimeric compounds were conjugated to oligonucleotides in order to improve their cellular uptake. Second and third generation lipophilic dendrimers were covalently attached either to the 5'- or 3'- end of oligonucleotides. Thermal denaturation experiments showed that the attachment of a third generation dendrimer leads to a substantial decrease in binding affinity. The considerably smaller second-generation dendrimers, however, are well tolerated. Fluorescence measurements revealed that the presence of a second-generation dendrimer leads to a marked increase in the cellular uptake of oligonucleotides.
\end{abstract}

Keywords: Antisense oligonucleotides, oligonucleotide-dendrimer conjugates, hybridization, cellular uptake

\section{Introduction}

There is considerable pharmaceutical interest in the use of synthetic oligonucleotides that intervene in the process of gene expression, such as antisense oligonucleotides ${ }^{1}$ or siRNAs. $^{2}$ Antisense oligonucleotides (ODNs) are designed to bind to mRNA in a sequence-specific manner. Subsequently, the bound mRNA is either degraded by RNaseH, or the mRNA is prevented from nuclear or ribosomal processing. ${ }^{3}$ Antisense oligonucleotides have been pursued as a major class of new pharmaceuticals for a variety of human diseases, including cancer and viral infections. ${ }^{4}$ Several limiting factors were encountered in the practical application of oligonucleotides. One factor is the low ability of these polyanionic molecules to traverse cell membranes. ${ }^{5-8}$ Numerous efforts have been made to increase the cellular uptake of antisense 
oligonucleotides by covalently attaching various chemical groups. Examples are conjugates with cationic compounds, such as poly-(L)-lysine ${ }^{9}$ or polyamides, ${ }^{10}$ lipophilic conjugates, such as cholesterol, ${ }^{11}$ long chain alcohols, ${ }^{12}$ phospholipids, ${ }^{13}$ aromatic compounds, ${ }^{14}$ as well as polyethylene glycol. ${ }^{15}$ Furthermore, the effect of attachment of these compounds at different position of the oligonucleotides including the bases, the backbone and the 3'- or 5' end was investigated. Uekama and coworkers reported that gene transfer activity was significantly improved by conjugates of $\alpha-, \beta-$, and $\gamma$-cyclodextrins with polyamidoamine starburst dendrimers. ${ }^{16}$ Most recently, lipophilic conjugates of siRNAs were used for gene-specific knockdown. ${ }^{17}$ In an attempt to increase the cellular concentration of oligonucleotides, we synthesized lipophilic dendrimeric building blocks and incorporated them into oligonucleotides. The influence of the dendrimer moiety on the oligonucleotide conjugates can readily be controlled by the size, the type and the number of the end groups. The dendrimeric compounds could act as 'nests' for a part of the conjugated oligonucleotide, and thereby improve their cellular uptake while still allow proper binding to its target sequence. The present paper describes the synthesis of various 5'- and 3'-oligonucleotide-dendrimer conjugates, their hybridization properties and uptake by $\mathrm{T} 24$ cells.

\section{Results and Discussion}

\section{Synthesis of the oligonucleotide dendrimer conjugates}

The dendrons 1 and 2 were prepared following the method of Frechet. ${ }^{18}$ Due to the large size of the dendrimers, adverse effects on the hybridization had to be expected. Therefore, we devised different linker moieties. The conversion of dendrimers $\mathbf{1}$ and $\mathbf{2}$ into activated N-hydroxy succinimide (NHS-) esters is shown in Scheme 1. NHS-esters $\mathbf{3}$ and $\mathbf{4}$ were obtained after the elongation of the second-generation dendron 1 and the third-generation dendron $\mathbf{2}$ with a benzyl linker group using $p$-bromomethylbenzoic acid. 


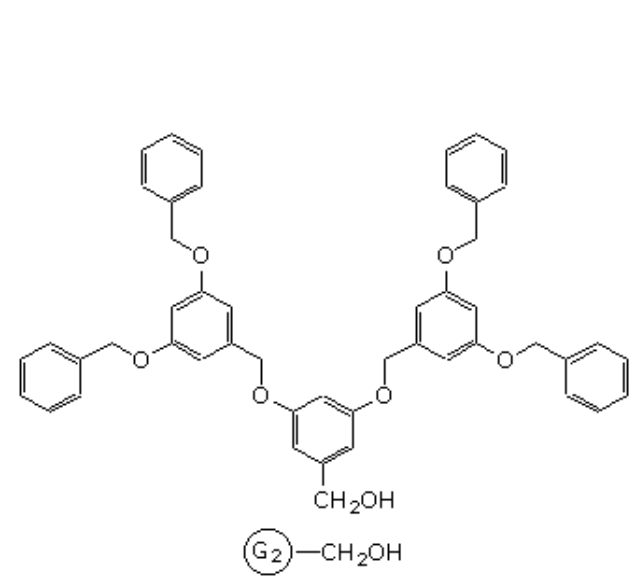

1

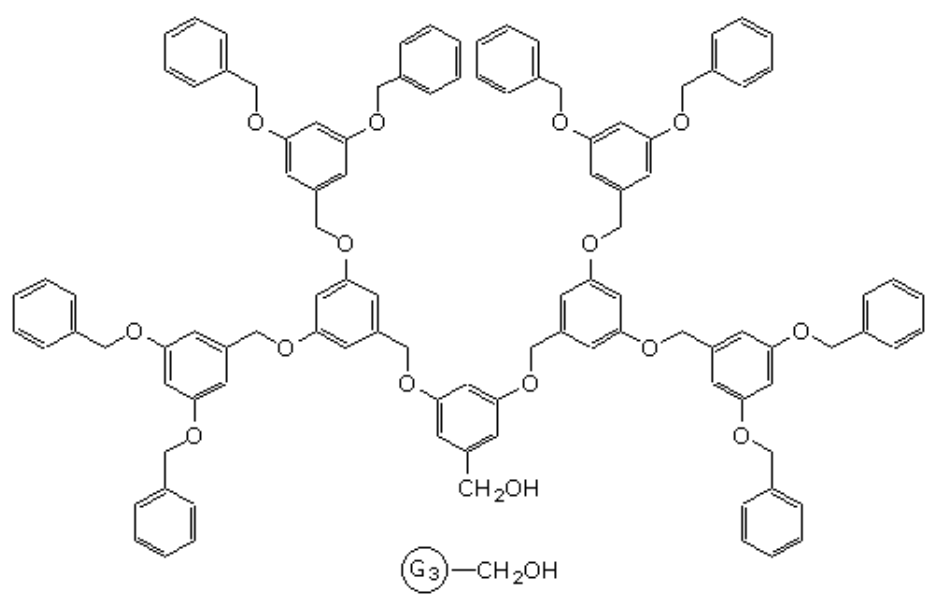

2

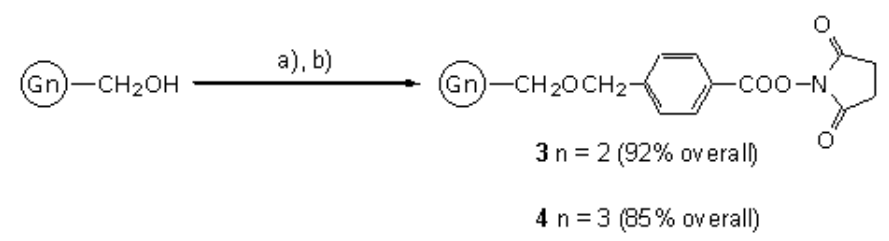

Scheme 1. Preparation of $N$-hydroxy succinimide esters of dendrons 1 and 2. Reagents and conditions: (a) $p$-bromomethylbenzoic acid, NaH, THF, reflux. (b) $N$-hydroxysuccinimide, DCC, rt.

For the synthesis of 3 '-oligonucleotide-dendrimer conjugates, a dendrimer-derived solid support was prepared. The procedure is illustrated in Scheme 2 for the second-generation dendrimer 1. The elongation of dendron 1 with $p$-bromomethylbenzoic acid in the presence of $\mathrm{NaH}$ in refluxing THF leads to the compound 5. The activated NHS-ester 6 was coupled to 3amino-1,2-propanediol. Compound 7 was then tritylated with 4,4'-dimethoxytrityl chloride (DMTCl). Succinylation of compound $\mathbf{8}$ was followed by activation with $p$-nitrophenol and coupling to the controlled pore glass $(\mathrm{CPG})$ solid support to yield the dendrimer-derived solid support product 11 with a loading of $30 \mu \mathrm{mol} / \mathrm{g}$. 


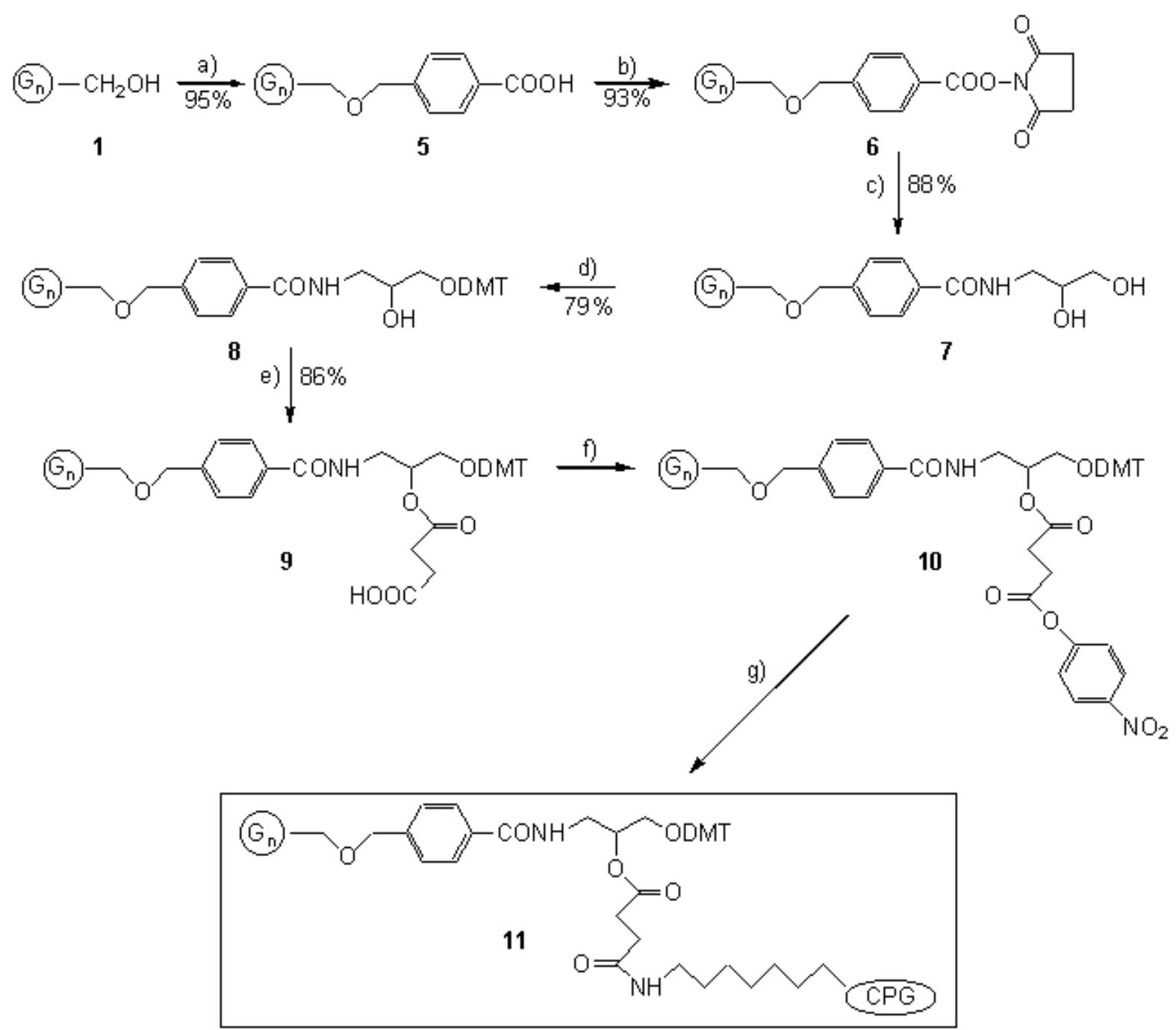

Scheme 2. Reaction scheme for the synthesis of a second generation dendrimer-derived solid support. Reagents and conditions: (a) p-bromomethylbenzoic acid, NaH, THF, reflux; (b) $N$ hydroxysuccinimide, DCC, rt. (c) 3-amino-1,2-propandiol, THF, rt, 3h, 50 C. (d) DMT-CI, pyridine, $0-20^{\circ} \mathrm{C}$. (e) succinic anhydride, DMAP, $\mathrm{Et}_{3} \mathrm{~N}, \mathrm{CH}_{2} \mathrm{CI}_{2}$, rt. (f) p-nitrophenol, DCC, pyridine, dioxane, rt. (g) long-chain aminoalkyl controlled pore glass, DMF, rt.

With the necessary activated ester and solid support in hands, the oligonucleotide conjugates 12 to 14 (shown in Table 1) and the fluoresceine labeled oligonucleotides 15 to 18 (see later, Scheme 3) were prepared. Incorporation of the elongated and $N$-hydroxy succinimide activated dendrimers to $5^{\prime}$-aminomodified oligonucleotide in $\mathrm{DMF} /$ dioxane/water at $40^{\circ} \mathrm{C}$ led to the oligonucleotide-dendrimer conjugates 12 and 13. The corresponding 3 '-oligonucleotidedendrimer conjugate 14 was assembled using the appropriate solid support 11 and standard phosphoramidite chemistry. ${ }^{19}$ Conjugates 15 to $\mathbf{1 8}$ contained a $5^{\prime}$-fluoresceine label, which was attached post-synthetically, through a 5'-aminolinker. After cleavage from the solid support and 
deprotection with aqueous ammonium hydroxide $\left(55^{\circ} \mathrm{C}\right.$, overnight $)$, the oligonucleotides were purified by reverse phase HPLC. Typical overall yields for a $1 \mu$ mole synthesis of reverse phase HPLC-purified oligonucleotide-dendrimer conjugates ranged from 20-25\%. The purity and identity of the obtained conjugates were verified by capillary gel electrophoresis and by matrixassisted laser desorption/ionization mass spectrometry.

Table 1. Sequences of oligonucleotide dendrimer conjugates 12 -14 synthesized and investigated by thermal denaturation experiments. Melting temperature (Tm) values of dendrimer conjugates were determined against the $15 \mathrm{mer}$ oligoribonucleotide 5'-UAUAUAUAUAAAAAA; total strand concentration was $2 \mu \mathrm{M}, \mathrm{pH} 7.4$ in phosphate buffer $(\Delta \mathrm{Tm}$ values are given as the difference in Tm relative to the reference oligonucleotide).

\begin{tabular}{|c|c|c|c|}
\hline Conjugate & Sequence & $\begin{array}{l}\mathrm{Tm} \\
{\left[{ }^{\circ} \mathrm{C}\right]}\end{array}$ & $\begin{array}{l}\Delta \mathrm{Tm} \\
{\left[{ }^{\circ} \mathrm{C}\right]}\end{array}$ \\
\hline (reference) & 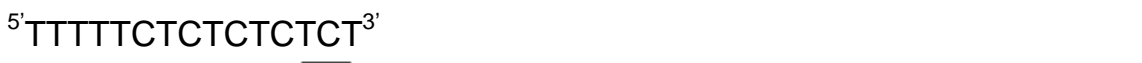 & 53.5 & - \\
\hline 12 & $>-\mathrm{CONH}\left(\mathrm{CH}_{2}\right)_{6} \mathrm{OP}\left(\mathrm{O}_{2}\right) \mathrm{O}-{ }^{-5} \mathrm{TTTTTCTCTCTCTCT}^{3}$ & 52.7 & -0.8 \\
\hline 13 & $\left(\mathrm{G}_{3}\right)-\mathrm{CH}_{2} \mathrm{OCH}_{2}<>-\mathrm{CONH}\left(\mathrm{CH}_{2}\right)_{6} \mathrm{OP}\left(\mathrm{O}_{2}\right) \mathrm{O}-{ }^{5} \mathrm{TTTTTCTCTCTCTCT}^{3}$ & 44.2 & -9.2 \\
\hline 14 & ${ }^{\text {ITTTTTCTCTCTCTCT}}{ }^{3}-\mathrm{P}\left(\mathrm{O}_{2}\right) \mathrm{O}_{\mathrm{OH}} \mathrm{H}\left(\mathrm{G}_{2}\right)$ & 56.5 & +3.0 \\
\hline
\end{tabular}

\section{Hybridisation properties of dendrimer conjugates}

The oligonucleotide-dendrimer conjugates 12, 13, and 14 were tested for their hybridization properties against a fully complementary RNA 15mer. As indicated in Table 1, thermal denaturation studies showed a marked drop $\left(\Delta \mathrm{Tm}=-9.2^{\circ} \mathrm{C}\right)$ in the melting temperature $(\mathrm{Tm})$ for the conjugate 13 containing the $\mathrm{G}_{3}$-dendrimer. The corresponding $\mathrm{G}_{2}$-dendrimer conjugate $\mathbf{1 2}$, however, showed only a slightly reduced $\mathrm{Tm}\left(\Delta \mathrm{Tm}=-0.8^{\circ} \mathrm{C}\right)$ compared with the unmodified oligonucleotide. The conjugate 14, bearing the second-generation $\left(\mathrm{G}_{2}\right)$ dendrimer on the 3 '-end showed even a slightly higher affinity $\left(\Delta \mathrm{Tm}=+3.0^{\circ} \mathrm{C}\right)$ compared with the unmodified oligonucleotide. All Tm curves showed a single cooperative transition (see Suppl. Material). These data indicate that the $\mathrm{G}_{2}$-dendrimer does not interfere significantly with the hybridization process.

\section{Cellular uptake of oligonucleotide dendrimer conjugates}

The influence of the dendrimer part on cellular uptake of the oligonucleotides was studied using fluoresceine-labeled PO (phosphodiester) and PS (phosphorothioate) second-generation dendrimer-conjugates (17 and 18) and the control oligonucleotides, fluoresceine-labeled PO and PS control oligonucleotides (15 and 16). 


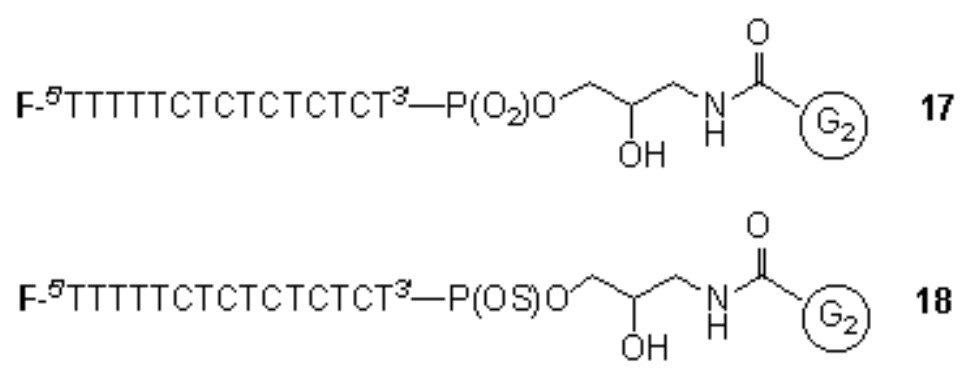

Scheme 3. Fluoresceine-labelled unconjugated PO (15) and PS (16) oligonucleotides and fluoresceine-labelled PO (17) and PS (18) oligonucleotide dendrimer-conjugates.

Fluorescence experiments revealed that covalent attachment of lipophilic dendrimers resulted in a substantial increase in the cellular association of oligonucleotides. Fluorescence microscopy was used to establish the intracellular accumulation of the oligonucleotide conjugates. Figure 2 shows the cellular uptake results obtained with T-24 cell cultures. A large increase in the cellular uptake was observed in the case of dendrimer conjugated oligonucleotides, both the phosphodiester and the phosphorothioate derivative.

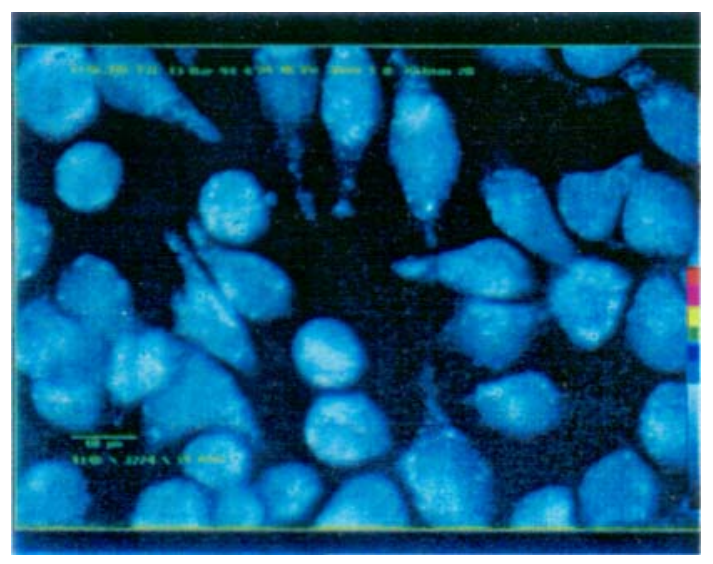

A

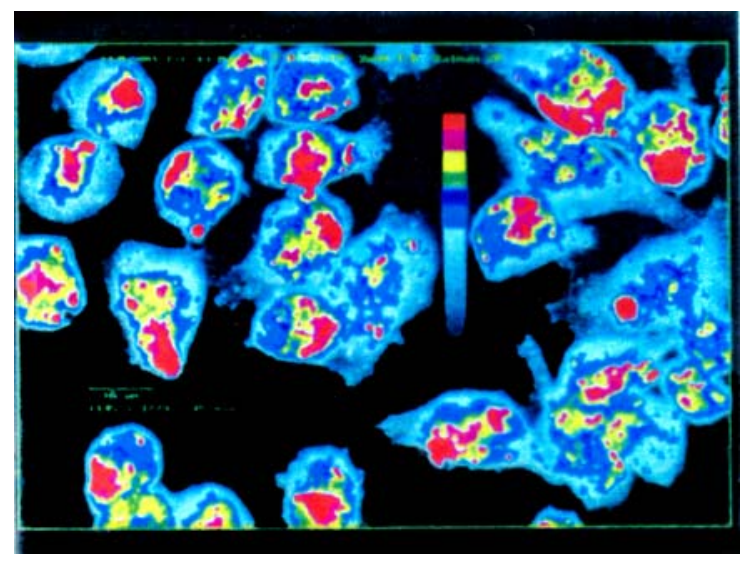

B 


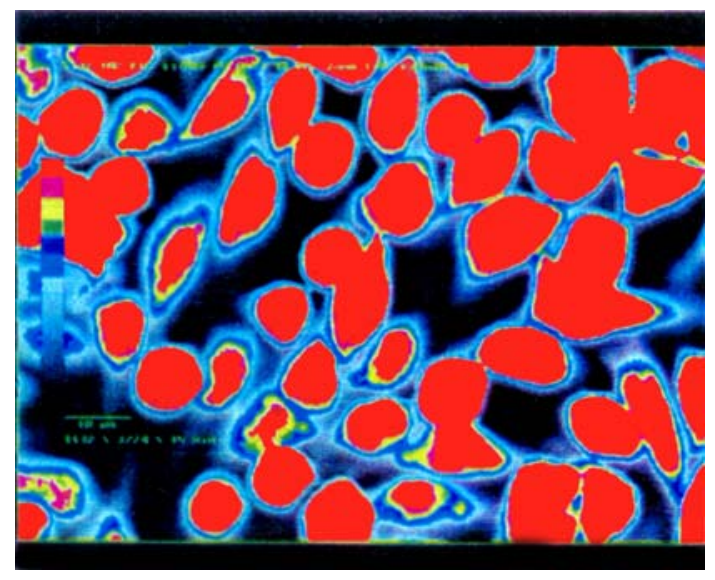

C

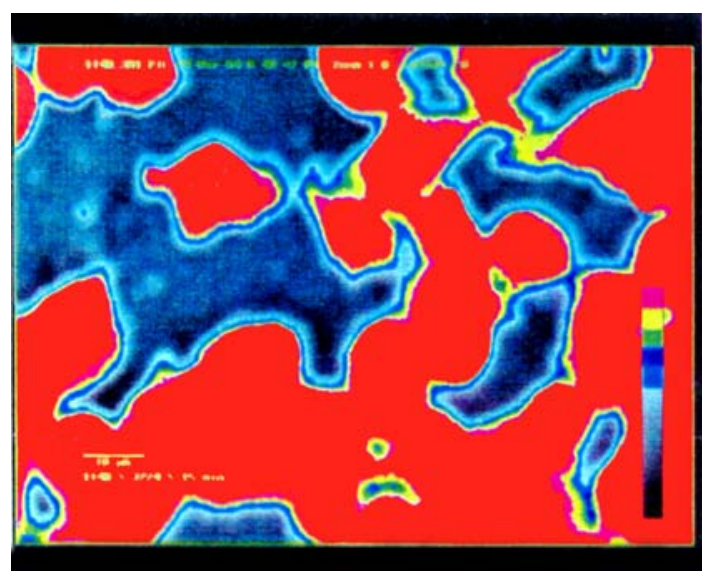

D

Figure 2. Intracellular association of modified oligonucleotides to T 24 cells after $15 \mathrm{~min}$. incubation. A) Fluoresceine-labelled PO control oligonucleotide 15 (analog of 17). B) Fluoresceine-labelled PS control oligonucleotide 16 (analog of 18). C) Fluoresceine-labelled POoligonucleotide-dendrimer conjugate 17. D) Fluoresceine-labelled PS-oligonucleotide-dendrimer conjugate 18.

Quantitation of the fluorescence (Figure 3) showed that the fluorescence was enhanced 11fold in the case of fluoresceine-labelled PO-oligonucleotide-dendrimer conjugate (17). The effect was even more pronounced in the case of the fluoresceine-labelled PS oligonucleotide-dendrimer conjugate (18) with a 15-fold enhancement of uptake. Thus, the dendrimer part of the conjugates acts as a lipophilic anchor and facilitates the penetration of the oligonucleotides through the cellular membrane.

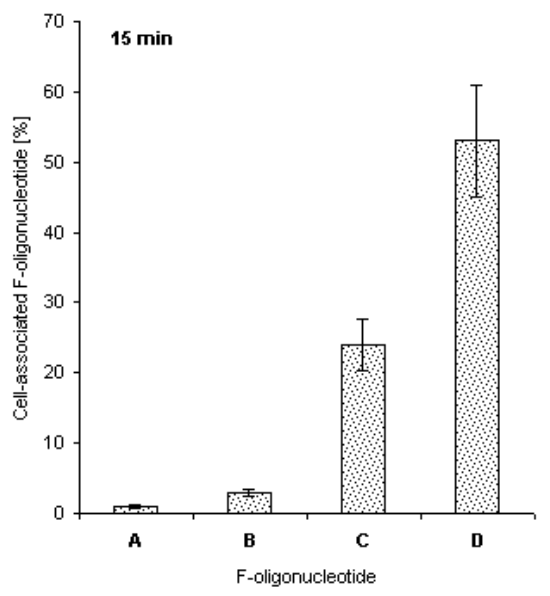

Figure 3. Estimated intracellular association of oligonucleotides to T 24 cells by fluorescence microscopy. A) fluoresceine-labelled PO control oligonucleotide 15 (analog of 17). B) fluoresceine-labelled PS control oligonucleotide 16 (analog of 18). C) fluoresceine-labelled POoligonucleotide-dendrimer conjugate 17. D) fluoresceine-labelled PS-oligonucleotide-dendrimer conjugate 18. 


\section{Conclusions}

We have shown that defined lipophilic oligonucleotide-dendrimer conjugates containing secondgeneration dendrimer building blocks at 5'- and 3'-terminus can be efficiently synthesized by use of $N$-hydroxy succinimide esters and by use of a dendrimer derived solid support. While the third generation conjugates show a reduction in $\mathrm{Tm}$, the hybridization properties of the secondgeneration dendrimer conjugates are very similar to the unconjugated oligonucleotides. The dendrimers have a pronounced influence on the cellular uptake of the oligonucleotides as demonstrated by fluorescence microscopy of labeled conjugates. Since our studies demonstrate that the second-generation (G2) 3'-oligonucleotide-dendrimer conjugates hybridize to their complementary nucleic acid targets and are taken up well by cells, these conjugates are of value as antisense agents.

\section{Experimental Section}

General Procedures. Solvents used were puriss, except for THF, which was purified by fresh distillation over $\mathrm{Na} /$ benzophenone. Commercially available reagents were used as received, without any further purification. Analytical TLC were performed on commercial Merck silica gel $60 \mathrm{~F}_{254}$. Flash chromatography was carried out using siliga gel 60 (230-400 mesh). ${ }^{1} \mathrm{H}$ NMR spectra were recorded on a Brucker AMX $(400 \mathrm{MHz})$ spectrometer using tetramethylsilane (TMS) as internal standard, chemical shifts are reported in ppm ( $\delta$ ) referenced to TMS, coupling constants $J$ in Hz. The dendrons $\mathbf{1}$ and $\mathbf{2}$ were synthesized as described. ${ }^{18}$ Oligonucleotides were prepared by automated synthesis on a $1.0 \mu \mathrm{mol}$ scale on a DNA synthesizer (Applied Biosystems inc. 394A-08). The crude oligonucleotide-dendrimer conjugates were purified by HPLC using a semi-preparative RP-C18 column [Hypersil ${ }^{\mathrm{TM}}, 5 \mu \mathrm{m}$ particle size; $50 \mathrm{mM}$ triethylammonium acetate (TEAA, $\mathrm{pH}$ 7.0). After concentration of the product-containing fractions, the purity was checked by capillary gel electrophoresis. The identity of the obtained oligonucleotide-denrimer conjugates was assessed by matrix-assisted laser desorption/ionization mass spectrometry.

Compound 5. To $\mathrm{NaH}(0.21 \mathrm{~g}, 9.0 \mathrm{mmol})$ in THF $(50 \mathrm{ml})$ was added the second generation dendron $1(2.0 \mathrm{~g}, 2.68 \mathrm{mmol})$ in THF $(50 \mathrm{ml})$. The mixture was stirred under reflux for $30 \mathrm{~min}$, then $p$-bromomethylbenzoic acid $(0.63 \mathrm{~g}, 2.95 \mathrm{mmol})$ was added at once. The reflux was maintained for $24 \mathrm{~h}$. After cooling to $0^{\circ}, \mathrm{H}_{2} \mathrm{O}(100 \mathrm{ml})$ was added slowly and then the mixture acidified with $10 \% \mathrm{HCl}$ soln. The precipitate, which formed was collected, washed with water, and dried over $\mathrm{P}_{4} \mathrm{O}_{10}$. The crude product was purified by flash chromatography $\left(\mathrm{CH}_{2} \mathrm{Cl}_{2}\right)$ to yield $6(2.18 \mathrm{~g}, 95 \%)$ as white amorphous solid. mp $153-155^{\circ} \mathrm{C} ;{ }^{1} \mathrm{H}$ NMR $\left(250 \mathrm{MHz}, \mathrm{CDCl}_{3}\right) \delta 8.04$ $(\mathrm{d}, J=8.49,2 \mathrm{H}), 7.43(\mathrm{~d}, J=8.49,2 \mathrm{H}), 7.39-7.31(\mathrm{~m}, 20 \mathrm{H}), 6.68-6.39(\mathrm{~m}, 9 \mathrm{H}), 5.03(\mathrm{~s}, 8$ benzyl. H), 4.99 (s, 4 benzyl. H), 4.61 (s, 2 benzyl. H), 4.49 (s, 2 benzyl. H). 
Compound 6. To an ice-cold solution of compound 5 (1.5 g, $1.70 \mathrm{mmol})$ in THF (50 ml), $N$ hydroxysuccinimide $(0.21 \mathrm{~g}, 1.85 \mathrm{mmol})$ and dicyclohexyl carbodiimide $(0.38 \mathrm{~g}, 1.85 \mathrm{mmol})$ were added and the mixture was stirred overnight at r.t. for $24 \mathrm{~h}$. The dicyclohexyl urea that formed was filtered off, the solvent was evaporated and the crude mixture was diluted in $\mathrm{CH}_{2} \mathrm{Cl}_{2}$ and washed with $\mathrm{H}_{2} \mathrm{O}$. The organic layer was dried $\left(\mathrm{MgSO}_{4}\right)$ and evaporated in vacuo. The crude product was purified by flash chromatography $\left(\mathrm{CH}_{2} \mathrm{Cl}_{2}\right)$ to yield $6(1.66 \mathrm{~g}, 93 \%)$ as a colorless oil. ${ }^{1} \mathrm{H}$ NMR (400 MHz, $\left.\mathrm{CDCl}_{3}\right) \delta 8.07(\mathrm{~d}, J=8.51,2 \mathrm{H}), 7.47(\mathrm{~d}, J=8.51), 7.40-7.29(\mathrm{~m}, 20$ H), 6.69-6.41 (m, 9 H), 5.04 (s, 8 benzyl H), 4.99 (s, 4 benzyl. H), 4.64 (s, 2 benzyl. H), 4.51 (s, 2 benzyl. H), 2.77 (s, $4 \mathrm{H})$.

Compound 7. Compound 6 (1.17 g, $1.2 \mathrm{mmol})$ was dissolved in THF (50 ml) and 3-amino-1,2propandiol $(0.13 \mathrm{~g}, 1.5 \mathrm{mmol})$ in THF $(10 \mathrm{ml})$ were added at r.t. The mixture was heated at $50{ }^{\circ} \mathrm{C}$ for $3 \mathrm{~h}$ and cooled to room temperature. The solvent was removed under reduced pressure and the residue was dissolved in $\mathrm{CH}_{2} \mathrm{Cl}_{2}$ and $\mathrm{H}_{2} \mathrm{O}$. The organic layer was dried $\left(\mathrm{MgSO}_{4}\right)$ and evaporated under reduce pressure and purified by flash chromatography $\left(\mathrm{CH}_{2} \mathrm{Cl}_{2} / \mathrm{MeOH} 10: 1\right)$ to yield $7(1.14 \mathrm{~g}, 88 \%)$ as a colorless oil. ${ }^{1} \mathrm{H}$ NMR (400 $\left.\mathrm{MHz}, \mathrm{CDCl}_{3}\right) \delta 8.08(\mathrm{~d}, J=8.51,2 \mathrm{H})$, 7.47 (d, $J=8.51,2 \mathrm{H}), 7.39-7.28$ (m, $20 \mathrm{H}), 6.80$ (br s, NH, $1 \mathrm{H}), 6.68-6.41(\mathrm{~m}, 9 \mathrm{H}), 5.03$ (s, 8 benzyl. H), 4.99 (s, 4 benzyl. H), 4.73 (br s, 1 H, CHOH), 4.64 (s, 2 benzyl. H), 4.57 (br s, $1 \mathrm{H}$, $\left.\mathrm{CH}_{2} \mathrm{OH}\right), 450$ (s, 2 benzyl. H), 3.88 (m, $\left.1 \mathrm{H}, \mathrm{CHO}\right), 3.47$ (m, $\left.2 \mathrm{H}, \mathrm{CH}_{2} \mathrm{O}\right)$, 3.07-3.02 (m, $2 \mathrm{H}$, $\mathrm{NCH}_{2}$ ).

Compound 8. Compound $7(0.95 \mathrm{~g}, 1.0 \mathrm{mmol})$ was dissolved in dry pyridine $(20 \mathrm{ml})$, and 1.1 equivalents of 4,4'-dimetoxytritylchloride $(0.37 \mathrm{~g}, 1.1 \mathrm{mmol})$ was added at $0^{\circ}$, and the mixture was stirred at room temperature until all the starting material had been consumed. Methanol $(0.2 \mathrm{ml})$ was added and stirring was continued for another $10 \mathrm{~min}$. Pyridine was distilled off and the mixture was co-evaporated with toluene. The residue was dissolved in $\mathrm{CH}_{2} \mathrm{Cl}_{2}$, extracted with diluted $\mathrm{NaHCO}_{3}$ solution and water, dried $\left(\mathrm{Na}_{2} \mathrm{SO}_{4}\right)$ and evaporated after addition of toluene. The residue was purified by flash chromatography $\left(\mathrm{CH}_{2} \mathrm{Cl}_{2}\right)$ to yield $8(0.99 \mathrm{~g}, 79 \%)$ as a colorless oil. ${ }^{1} \mathrm{H}$ NMR (400 MHz, $\left.\mathrm{CDCl}_{3}\right) \delta 8.04$ (d, $\left.J=8.50,2 \mathrm{H}\right), 7.43$ (d, $\left.J=8.50\right), 7.40$ 6.74 (m, 33 arom. H, NH, 1 H), 6.70-6.42 (m, 9 H), 5.02 (s, 8 benzyl. H), 4.99 (s, 4 benzyl. H), 4.89 (br s, 1 H, OH), 4.62 (s, 2 benzyl. H), 4.51 (s, 2 benzyl. H), 3.73 (m, 1 H, CHO), 3.67 (s, 6 $\left.\mathrm{H}, \mathrm{OCH}_{3}\right), 3.10-3.03\left(\mathrm{~m}, 2 \mathrm{H}, \mathrm{NCH}_{2}\right), 3.02\left(\mathrm{~m}, 2 \mathrm{H}, \mathrm{CH}_{2} \mathrm{O}\right)$.

Compound 9. To a solution of $8(0.63 \mathrm{~g}, 0.5 \mathrm{mmol})$ in $\mathrm{CH}_{2} \mathrm{Cl}_{2}(10 \mathrm{ml})$ and trietylamine $(1.0 \mathrm{ml})$, succinic anhydride (50 mg, $0.5 \mathrm{mmol}$ ) and 4-dimethylaminopyridine (30 mg, $0.25 \mathrm{mmol})$ were added and the mixture was stirred overnight at r.t. When the reaction was complete (TLC control), triethylamine was distilled off and the mixture was co-evaporated with toluene. The residue was dissolved in $\mathrm{CH}_{2} \mathrm{Cl}_{2}$, extracted with diluted $\mathrm{NaHCO}_{3}$ solution and water, dried $\left(\mathrm{Na}_{2} \mathrm{SO} 4\right)$ and evaporated after addition of toluene. The residue was purified by flash chromatography $\left(\mathrm{CH}_{2} \mathrm{Cl}_{2} / \mathrm{MeOH} 10: 1\right)$ to yield $9(0.58 \mathrm{~g}, 86 \%)$ as white amorphous solid. mp 187-190 ${ }^{\circ} \mathrm{C} ;{ }^{1} \mathrm{H}$ NMR $\left(400 \mathrm{MHz}, \mathrm{CDCl}_{3}\right) \delta 8.02(\mathrm{~d}, J=8.50,2 \mathrm{H}), 7.41(\mathrm{~d}, J=8.50), 7.40-6.74$ (m, 33 arom. H, NH, 1 H), 6.70-6.42 (m, 9 H), 5.02 (s, 8 benzyl. H), 4.98 (s, 4 benzyl. H), 4.62 
(s, 2 benzyl. H), 4.51 (s, 2 benzyl. H), 3.73 (m, $1 \mathrm{H}, \mathrm{CHO}), 3.67$ (s, $6 \mathrm{H}, \mathrm{OCH}_{3}$ ), 3.10-3.03 (m, 2 $\left.\mathrm{H}, \mathrm{NCH}_{2}\right), 3.02\left(\mathrm{~m}, 2 \mathrm{H}, \mathrm{CH}_{2} \mathrm{O}\right), 2-58-2.71\left(\mathrm{~m}, 4 \mathrm{H}, \mathrm{CH}_{2} \mathrm{CH}_{2}\right)$.

Compound 10. Compound $9(0.5 \mathrm{~g}, 0.37 \mathrm{mmol})$ was dissolved in anhydrous dioxane $(10 \mathrm{ml}) /$ pyridine $(1 \mathrm{ml})$. p-Nitrophenol $(51 \mathrm{mg}, 0.37 \mathrm{mmol})$ and dicyclohexyl carbodiimide $(0.2 \mathrm{~g}, 1.0 \mathrm{mmol})$ were added and the mixture was stirred overnight at r.t. The dicyclohexyl urea that formed was filtered off, the solvent was evaporated and the crude mixture was diluted in $\mathrm{CH}_{2} \mathrm{Cl}_{2}$ and washed with $\mathrm{H}_{2} \mathrm{O}$. The organic layer was dried $\left(\mathrm{MgSO}_{4}\right)$ and evaporated in vacuo. The crude product was used without any further purification.

Dendrimer-derived solid support 11. The crude compound $\mathbf{1 0}$ was added to a suspension of long chain alkylamine controlled pore glass (CPG) $(6 \mathrm{~g})$ in DMF $(20 \mathrm{ml})$. After $24 \mathrm{~h}$, the glass was filtered off and washed excessively with DMF, methanol and ether, and dried in vacuo. For capping of unreacted amino groups, a mixture of $2 \mathrm{ml}$ acetic anhydride and $100 \mathrm{mg}$ 4dimethylaminopyrimidine in $20 \mathrm{ml}$ dry pyridine was added to the support. After standing for $1 \mathrm{~h}$ at room temperature, the support was filtered off, washed extensively with acetonitrile and ether and dried in vacuo. A dimethoxytrityl cation assay showed a loading of $30 \mu \mathrm{mol}$ of DMTrgroups per gram of $\mathbf{1 1}$.

\section{References and Footnotes}

1. (a) Helene, C.; Toulme, J. Biochim. Biophys. Acta 1990, 99, 1049. (b) Braasch, D. A.; Corey, D. R. Biochemistry 2002, 9, 41, 4503. (c) Dean, N. M.; Bennett, C. F. Oncogene 2003, 8, 22 (56), 9087. (d) Retter, A. S.; Gulley, J. L.; Dahut, W. L. Cancer Biol. Ther. 2004, 3 (4), 371. (e) Da Ros, T.; Spalluto, G.; Prato, M.; Saison-Behmoaras, T.; Boutorine, A.; Cacciari, B. Curr. Med. Chem. 2005, 12, 71. (f) Rieber, M.; Strasberg-Reiber, M. Methods Mol. Med. 2005, 106, 205. (g) De Mesmaeker, A.; Häner, R.; Martin, P.; Moser, H. E. Acc.Chem.Res., 1995, 28, 366.

2. (a) Martinez, J.; Patkaniowska, A.; Urlaub, H.; Luhrmann, R.; Tuschl, T. Cell 2002, 110(5), 563. (b) Hall, J. Nature Reviews Genetics 2004, 5, 552.

3. Uhlmann, E.; Peyman, A. Chem. Revs. 1990, 90, 543.

4. Stephenson, M. L.; Zamecnik, P. C. Proc. Natl. Acad. Sci. U.S.A. 1978, 75, 285.

5. Polushin, N. N.; Cohen, J. S. Nucleic Acids Res. 1994, 22, 5492.

6. Stein, C. A.; Ranajit, P.; De Vico, A. L.; Mumbauer, S.; Kinstler, O.; Sarngatharan, M. G.; Letsinger, R. L. Biochemistry 1991, 30, 2439.

7. Curiel, D. T.; Agrawal, S.; Wagner, E. Proc. Natl .Acad. Sci. U.S.A. 1991, 88, 8850.

8. Bonfils, E.; Mendes, C.; Roche, A. C.; Monsigny, M.; Midoux, P. Bioconjugate Chem. 1992, 3, 277.

9. Leonetti, J. P.; Rayner, B.; Lemaitre, M.; Gagnor, C.; Milhaud, P. G.; Imbach, J. L.; Lebleu, B. Gene 1988, 72, 323.

10. Haralambidis, J.; Duncan, L.; Angus, K.; Tregear, G. W. Nucleic Acids Res. 1990, 18, 493. 
11. MacKellar, C.; Graham, D.; Will, D. W.; Burgess, S.; Brown, T. Nucleic Acids Res. 1992, 20, 3411.

12. Boiziau, C.; Toulmé, J. J. Biochimie. 1991, 73, 1403.

13. Ramirez, F.; Mantal, S. B.; Marecek, J. F. J. Am. Chem. Soc. 1982, 104, 5483.

14. Kuyl-Yeheskiely, E.; Dreef-Tromp, C. M.; Geluk, A.; van der Marel, G. A.; van Boom, J. H. Nucleic Acids Res. 1989, 17, 2897.

15. Jäschke, A.; Fürste, J. P.; Nordhoff, E.; Hillenkamp, F.; Cech, D.; Erdmann, V. A. Nucleic Acids Res. 1994, 22, 4810.

16. (a) Kihara, F.; Arima, H.; Tsutsumi, T.; Hirayama, F.; Uekama, K. Bioconjugate Chem. 2003, 14, 342. (b) Arima, H.; Wada, K.; Kihara, F.; Tsutsumi, T.; Hirayama, F.; Uekama, K. J. Incl. Phen. and Mol. Recogn. 2002, 44, 361.

17. (a) Lorenz, C.; Hadwiger, P.; John, M.; Vornlocher, H. P.; Unverzagt, C. Bioorganic and Medicinal Chemistry Letters 2004, 14, 4975. (b) Soutschek, J.; Akinc, A.; Bramlage, B.; Charisse, K.; Constien, R.; Donoghue, M.; Elbashir, S.; Geick, A.; Hadwiger, P. ; Harborth, J.; John, M.; Kesavan, V.; Lavine, G.; Pandey, R. K.; Racie, T.; Rajeev, K. G.; Rohl, I.; Toudjarska, I.; Wang, G.; Wuschko, S.; Bumcrot, D.; Koteliansky, V.; Limmer, S.; Manoharan, M.; Vornlocher, H. P. Nature 2004, 432, 173.

18. Hawker, C.-J.; Fréchet, J. M. J. J. Am. Chem. Soc. 1990, 112, 7638.

19. Barone, A. D.; Tang, L.-Y.; Caruthers, M. H. Nucleic Acids Res. 1984, 12, 4051. 